\title{
Construction of Social Cohesion and Living Together in the Cameroonian Public Space: Differences of Opinion versus the Emergence of a Common Sense in Discourse
}

\author{
Corine Esse \\ Department of Corporate Communication, Advanced School of Mass Communication (ASMAC), University of Yaounde II, \\ Yaounde, Cameroon \\ Email: princessecorine820@gmail.com
}

How to cite this paper: Esse, C. (2021) Construction of Social Cohesion and Living Together in the Cameroonian Public Space: Differences of Opinion versus the Emergence of a Common Sense in Discourse. Int. J. Communications, Network and System Sciences, $14,75-94$

https://doi.org/10.4236/ijcns.2021.146006

Received: May 31, 2021

Accepted: June 27, 2021

Published: June 30, 2021

Copyright $\odot 2021$ by author(s) and Scientific Research Publishing Inc. This work is licensed under the Creative Commons Attribution International License (CC BY 4.0).

http://creativecommons.org/licenses/by/4.0/

\begin{abstract}
Social cohesion and living together increasingly appear to be a response by the public authorities to the emergence of identity claims in Cameroon, in a context marked by the Anglophone crisis. Indeed, the socio-historical evolution reveals that living together in Cameroonian society changes considerably according to the social crises that animate it. It is therefore necessary to question the construction of these two concepts, in a dynamic marked by the reconfiguration of the public space characterised by occurrences in journalistic discourse. The aim of this proposal is to analyse the different conceptions that emerge from debates on cohesion and living together in the Cameroonian public space, in order to detect the true meaning that emerges from them. Our general objective is to explore the possibilities of constructing a problematic in the public space, namely living together, based on what is said by the actors in televised debates. The observation of the public space in particular that circumscribed by televised debates, reveals a frequency of their discursive use. The questions we asked ourselves were the following: How are the notions of living together and social cohesion constructed in televised debates in Cameroon? How do citizens position themselves in the face of the multitude of identity allegiances with which they identify in the public space? In order to provide some answers to this question, we observed and analysed the statements made by actors on stage in televised debates on four television channels. We were particularly interested in the debates on living together and social cohesion, and by means of discourse analysis we were able to detect the content of these notions. Our analysis of the television debates shows that social cohesion is presented as the manifestation of "living together", in the sense that it implies
\end{abstract}


an interweaving of identities between the different strata of the population with a view to their full participation in the construction of the whole society. Furthermore, "living together" is conditioned by the requirements of good governance, whereas at the level of public authorities, it is seen more as a political option.

\section{Keywords}

Social Cohesion, Living Together, Discourse Analysis, Television Debates

\section{Introduction}

Social cohesion and citizenship are the first conditions for sustainable human development. They enable all members of society to contribute, according to their competences, to this development and to the creation of wealth. In particular, social cohesion is the capacity of a society to ensure the well-being of all its members. In Cameroon, social cohesion and living together are increasingly seen as a response by the public authorities to the emergence of identity-based claims, in a context marked by the Anglophone crisis. As Jacqueline Nkoyok [1] points out, the socio-historical evolution reveals that living together in Cameroonian society changes considerably according to the social crises that animate it. It is therefore necessary to question the construction of these two concepts, in a dynamic marked by the reconfiguration of the public space characterized by occurrences in journalistic discourse. Our research takes place in a context where the living together that structures the relations between ethnic and cultural communities and social cohesion are really put to the test in Cameroon. Indeed, in Cameroon, a country with more than 250 ethnic groups, the Anglophone demands that emerged in 2016 lead to the question of living together as an ideal or a challenge. The challenge of living together could be the management of the more or less veiled desire to withdraw into one's own identity on the part of various social actors. In this delicate context, identity-based withdrawal is revived by several socio-political phenomena that hinder the dynamics of harmonious development. The aim of this proposal is therefore to analyse the different conceptions that emerge from debates on cohesion and living together in the Cameroonian public space, in order to detect the true meaning that emerges from them, in a context of identity and political claims. Our research is situated at the intersection of the phenomena of media, visibility and the construction of problems in the public sphere. The relevance and topicality of the problematic we are studying justify the interest of researchers in recent years.

Based on the above observation, Mbarga [2] examines and highlights the challenges of governance in a context of ethnic and cultural plurality. Through a socio-historical analysis, the aim was to show how systematizing the precepts of good governance would make the multicultural and diverse character of a human society an asset for development. The author concludes that in Cameroon, 
the survival of identity-based withdrawal stems from a socio-historical configuration based on a deficit of good governance of the State, the division, construction and consolidation of which remain essentially a colonial and neo-colonial legacy. On his part, Avodo [3] describes the pre-construction of living together in the Cameroonian discursive space base on the study of four types of political discourse. The analysis, which is based on the hypothesis of an ideological continuum and founded on dialogism, reveals that the repetition of the pre-constructs at all the levels of formulation leads to the stabilization of the ideology of living together in the collective memory. By constructing and disseminating the idea of a united, democratic and social republic, the networks of formulation and lexico-semantic network of living together give every citizen the feeling of belonging to the same nation. The author postulates that living together appears to be a social construction, a mutual and consenting commitment towards a collective consciousness. Moreover, living together is a pre-construct, a social referent whose original source and path are more or less known.

Kameni Wendeu [4] on her part took a panoramic look at two dailies: "Cameroon Tribune" and "Le Messager". The author recognizes that the North-West and South-West regions of Cameroon are affected by a crisis that weakens the unity of the country. This crisis, which began in 2016, calls into question the way people live together, a value that is very dear to the Cameroonian people. In this climate of confusion, the press plays a major role as it participates in political debate. The author intended to decipher the impact of media discourse on the construction of living together in Cameroon. The corpus of her study provides understandings on how this type of discourse contributes to the construction of living together in a context of crisis. It emerges that the argumentative orientation of the discursive construction of living together is strongly influenced by the ideological-discursive positioning of the two newspapers. The author concluded by stating that the media construct a fragmented vision of the public space and impose it on the public.

The present research is in line with studies on the construction of the notion of living together in the public space. The general objective is to explore the possibilities of constructing a problematic in the public space, namely living together. The specific objective is to examine the way in which televised debates in Cameroon can contribute to the appearance of contents in the public sphere on the subject of social cohesion and living together. The observation of the public space, particularly that circumscribed by televised debates, reveals a frequency of their discursive use. From a constructivist perspective, the analyses aim to show the relationship between political transformations and the discursive dynamics around these two concepts, in a movement of decomposition and reconstruction of identities (Balandier) [5]. The convocation of the public space in the framework of the present reflection allows us to grasp the discursive disparities between the debates on social cohesion, living together and the conception of the public authorities. In other words, how do citizens position themselves in the face of the multitude of identity allegiances with which they identify through the public space? 
Do social cohesion and living together as represented in the discourses in Cameroon emanate from public policies or are they simply a sociological observation of actors in action during televised debates?

From a multidisciplinary position that draws on the sources of information and communication sciences on the one hand and political sciences on the other, this research attempts to show how living together is constructed on television sets. To do this, the discourse analysis technique was used as bases for observations and analyses of words and interventions of various actors on stage during television debates in four programs during the period 2018-2019. The aim was to contribute to the debate on the construction of emerging concepts, which are used as a response to identity crises, but whose understanding is made complex by the divergence of discourse in the public space.

\section{Theoretical Positioning: Symbolic Interactionism}

The theoretical framework that was used in this study is situated in the epistemological extension of symbolic interactionism, developed in part in the work of Erwing Goffman. The aim is to detail the logic of identity inscribed in the interactions during televised debates on the subject of living together and to show that the meaning of what is said goes beyond the strict propositional content, which in this case, often proves to be quite modest and uncomplicated. Such a theoretical approach is thus articulated around argumentative discourse as a driving force in the construction and negotiation of social realities. It postulates that these "emerge from communication activities [...] which constrain the organization and meaning of discourse at the same time as discourse produced in similar contexts shapes the properties of these activities" (Burger) [6]. Indeed, it is a question of the panelists (debaters) confronting each other on a television set, defining and positioning themselves with regard to the opposing party, in other words, saying themselves by opposing themselves (Amossy) [7]. It is therefore from a "constructionist" perspective of identity, referring to the Goffmanian notion of "self", that we were interested here in the discursive aspects of self-presentations in situations of conflictual interactions around debates on living together. Goffman's symbolic interactionism is based on a dramaturgical approach to social interactions and gives a central place to the definition that the protagonists make of the enunciation situation, which is a co-construction and no longer a static datum, thus breaking away from the traditional paradigm of the "speaker-listener" envisaged by the code model and based on an immanentist linguistics, inherited from the first philosophies of language and centred on the notion of identity.

This perspective thus departs from the classical conceptions of argumentation which pose as an objective, an ideal argumentative discourse, which would be above all rational, free of time constraints, obeying the rules of reasoned dialogue of Habermas (Doury et al.) [8]. In this case, the argumentative character of the speeches does not depend on a judgment of rationality but on the intrinsic characteristics of the speech and in particular, on the relation it constructs to a 
counter-speech which it stages and in relation to which it defines itself. The activity of argumentation therefore no longer involves the evaluation of "classical" argumentative figures (the paradigm of persuasion) but is a matter of negotiation and the co-construction of identities.

If we admit that argumentation is dialectical, then its language is not a language of objects, but a language inhabited by the interlocutors and marked by their points of view (Plantin) [9]. The identity and the social aspect that constitutes it are then made "accessible" by the forms and discursive activities of the interlocutors. Thus, beyond the consideration of social contexts and issues, the main indicators of the expectation patterns underlying the interpretation of argumentative discourse are first and foremost the role identities assumed by the various interlocutors (Fortin) [10]. During a televised debate, the interlocutors are inscribed within a space that is co-managed according to a certain communicational stake; the identity of the subjects can only be understood in relation to other identities in a space of dialogue, in relation to the communicational recognition of which it is the object. Identities are thus no longer conceived as isolated and unique, but as the result of the joint and evolving activity of subjects in contact. Thus, the essential part of discursive productions, in the televised debates which constituting our corpus, lies in the will to construct/propose an image of oneself and of others, which can serve the argumentative objectives.

Indeed, in a televised debate, the staging of the communicative competence of the interlocutors requires the institution of a certain number of codes, reference points, "rites" and criteria (true/false, logical/illogical, lucid/utopian), figures (power, knowledge, legitimacy, etc.). This is what justifies the choice of symbolic interactionism in this study.

\section{Methodological Approach}

Immediately this research topic was defined, the dilemma faced was the choice of analytical tools, given that we could use both discourse analysis and content analysis. It should be noted that the research corpus was constituted of the media, in this case the television. The televised discourse produced through televised debates is argumentative. For Adam [11], "an argumentative discourse aims to intervene on the opinions, attitudes or behaviors of an interlocutor or an audience by making a statement credible or acceptable”. Bourdieu [12], Ducrot [13], Ghiglione and Matalon [14], Kerbrat-Orecchioni [15] agree that a discourse does not simply describe a pre-existing reality but constructs the representation of reality that the speaker wishes to share with the addressee. As a result, for most language specialists, uttering a discourse means wanting to act on others. Speech thus has a performative objective: it is a voluntaristic act of influence. The discourse we wish to analyze here is the television news discourse.

Any argumentative discourse then inscribes in its statement a representation of the transmitter and the receiver and implicitly reveals the nature of the relations between the two poles of the exchange. The information conveyed through 
televised debates and news discourse in general is a moment of the television grid and its characteristics are shaped in relation to other television genres as well as to other news discourse. The contract at the basis of the news discourse is founded on an imperative of credibility, which is reflected in the whole scenography of televised debates: the referential obsession, the role of live broadcasting, a discourse which is entirely organised around an imaginary of truth (exhaustiveness, plurality of points of view, etc.). But in parallel to this imperative of credibility at the base of the information contract, the discourse resulting from televised debates must be produced according to the discursive rules specific to the television medium so as not to be contrary to the principle of capture at the base of the televised discourse as a whole: hence the presence of a presenter and all the staging with the panelists, the setting of the plot. Shaped by its context and its communication co-text, the television discourse cannot be understood outside of these elements which structure it throughout. As we can see, the context, here no more than anywhere else, is never simply placed around a statement, but is primary in the meaning of the statement: there is no discourse media/television that is not contextualized. Once we have established the fact that television discourse is unthinkable outside of these co-textual and contextual elements that ground and structure it throughout, we can draw methodological consequences from this and from the corpus.

In discourse analysis, "any enunciative activity is related to a genre of discourse: the social place from which it emerges, the channel through which it passes (oral, written, televised), the type of dissemination it implies, cannot be dissociated from the way in which the text is organized" (Maingueneau,) [16]. Discourse analysis poses the question of the corpus differently, the emphasis is placed elsewhere. Exhaustiveness, nor homogeneity, is not an objective; rather, it is the privileged moments, the specific passages of a corpus that interest it, the fracture lines where the link between utterance and enunciation is expressed, the relationship between emission, production and reception. This is the case, for example, in Véron's [17] famous study, where he analyses the functioning of the enunciation device specific to television news. To do this, he chose key moments in the audiovisual discourse where the presenter's strategy of capturing the viewer (he looks him "in the eye" and guides his gaze to other places) is most clearly expressed which in fact constitutes the specificity of the enunciation device.

Unlike content analysis, which is based on perfectly usual operations (locating lexical or syntactic units, classifying, counting, etc., and then interpreting them), discourse analysis is based on elements that are partly intuitive; apart from the principles set out above, each discursive grouping will generate elements for its own analysis, and each problem will generate the specific tools for its exploration. Thus, elements such as: the performative objective of the discourse as a voluntary act of influence; the context for understanding the statements; the presence of markers or traces of persuasion have enabled us to develop our analysis 
grid.

Therefore an analysis grid was developed based on the study of enunciative, referential and organisational indicators: analysis of the enunciation system; analysis of the discourse referential, i.e. the main semantic fields and analysis of the argumentative circuit, i.e. the nature and structure of the arguments. Our corpus was made up of five programs, one broadcasted on the national television channel (CRTV) and four on private television channel (Canal 2 International, Vision 4 and Equinoxe). These programs are: Scènes de presse (CRTV); L'Arène (Canal 2 International); Club délite (Vision 4) and Droit de réponse (Equinoxe). A total of thirty programs were broadcasted between 2017 and 2019 These programs which are the subject of this study were considered to be informative, whose contradictory nature would evoke in audiences the face of an open society (Matsanga Nziengui) [18]; insofar as they are similar to places of expression of cultural diversity. Furthermore, our select was because these are popular debate programs with a fixed regularity (every Sunday). The programs usually featured a moderator and guests on a television set. In the case of Scènes de Presse, in addition to the moderator, the panel is composed of invited guest protagonists coming to explain a fact or facts and one or more columnists.

All the programs chosen are of the "televised debate" type (Nel) [19] because of their scenic layout (circular), the choice of guests (politicians, senior officials, civil society figures, journalists, etc.), the status of the moderator and the notoriety of the columnists, who have sometimes become regular figures on the stage. These debates are often very heated and produce discourses which, in their textual manifestation, are in dissociable from their conditions of production, as much as from the scenic devices of which they are one of the intrinsic components. The interest in media debates is further justified by the fact that they are characterized by a set of conflicting practices and occurrences. One could even rightly attribute to them a dimension (Rouquette) [20] as places par excellence of verbal jousting. Nga Ndongo [21] states that these are exchanges, often discourteous, acerbic, even hateful, between the panelists and that they essentially revolve around power conceived as a question of life and death. He goes on to say that these debates reflect or reveal, in any case, the zero degree, i.e. zero, of the "political game" in a country that is geo-culturally mosaic, fragile and laboriously engaged in the process of building a compelling national consensus. Charaudeau and Ghiglione [22] defined televised debates as "a form of exchange organised in such a way as to bring out the truth, whatever its configuration, about a problematized thematic, through the confrontation of different types of knowledge on the thematic, by means of a televisual device (organization, management, display) which allows the exhibition of this knowledge and its confrontation to bring out certain aspects of the problematization while being as intelligible as possible" (year, page).

\section{Living Together as an Ideal of Mixing Communities}

The expression "Living together", which has been gaining ground in political dis- 
course of recent despite the fact that its use dates back several years, is almost always linked to conflictual contexts. It thus attempts to capture the complexity of human relations from various angles: sociology, anthropology, geopolitics, political science, etc. The multiplication of conflicts on the planet and the desire to reach appeasement situations have favored the emergence of concepts such as the social link, social cohesion and living together. Taking the measure of social relations, the United Nations [23] proclaimed 2019 as the International Year of Moderation and 16 May as the International Day of Living Together in Peace. This proclamation is intended as a means of regularly mobilizing the international community's efforts in favor of peace, tolerance, inclusion, understanding and solidarity, and as an opportunity for all to express the deep desire to live and act together, united in difference and diversity, in order to build a sustainable world based on peace, solidarity and harmony.

In contrast to living apart, living together requires ongoing negotiation that allows us to question ourselves collectively. According to Fall [24], in its substantivized form, living together:

“arises from an interaction between protagonists, bearers of recognized singularities, but also inhabited by universal moral principles, who jointly elaborate a dialogical framework recognizing freedom of expression and respect between the interactants. This dialogue is driven by the desire to produce the "negotiated common" and to foster social cohesion" (p. 32).

Thus, at the heart of this identity process are tensions between the person as an individual and the person as a citizen, between the self and others (Broquet) [25], between the diversity of people and cultures and the unity of a society (Touraine) [26], between the desire to respond to the needs and desires of others and the place of authority in a democratic context. Living together is defined as "harmonious cohabitation between individuals or between communities" (Larousse) [27]. It is a concept that expresses the peaceful links of good understanding that individuals, peoples or ethnic groups have with others in their living space or territory. Living together includes cultural diversity, social inclusion, social and solidarity economy, alternatives, collective entrepreneurship, networking, territorial dynamics, valorization of endogenous potentials among others. It thus appears as a new form of governance integrating cultural diversity, social mix, living environment, community development and participatory finance. Living together is about fostering a sense of belonging for all, promoting cultural diversity, well-being and security for all, fostering social and economic inclusion, developing innovative and sustainable practices that promote both social and economic inclusion, improving the quality of life, cultural diversity, security, culture, the environment, employment and good public governance, and above all, better managing diversity, equality and the economic and social inclusion of fellow citizens. The issue of living together is of paramount importance in the daily relations of a country's citizens. Indeed, the mobility of populations creates an environment where cities must deal with new situations that pose challenges of social cohesion, cultural diversity, urban planning, and which are of primary con- 
cern to local authorities.

In Cameroon, the preamble to the Constitution stresses in this respect that "the State shall ensure the protection of minorities' and promote "linguistic and cultural diversity" (Constitution of Cameroon) [28]. It should be noted that the country has made cultural diversity a major political concern since 1996 . This position is justified by the fact that the country has over 250 ethnic groups. Beyond what is written in the fundamental law, a new body for the promotion of cultural diversity was created in 2017 with the creation of the National Commission for the Promotion of Bilingualism and Multiculturalism, with the main aim of strengthening the will and daily practice of living together of its populations. Since 2016, the country has been experiencing unrest, both internally with two security and socio-political dysfunctions (the Boko Haram phenomenon and the Anglophone crisis) and in terms of international cooperation. The feeling of belonging to a common nation does not seem to sweep away identity, ethnic and social aspirations. Ethnic and cultural rivalries in some parts of the country have already become apparent. These frustrations are the result of the exacerbation and instrumentalization of differences that give rise to conflicts in the Cameroonian social milieu, despite the official discourse on the consolidation of an integrated, united and strong nation. Living together is therefore put to the test under these conditions, where it should be noted that the promotion of diversity is not a matter of public action whose only operator would be the state. It involves several other actors such as the media. It is this role of the media in building social cohesion that was be examined in this contribution.

This paper thus examines how this expression can either name a social reality, or refer to a normative framework, which aims at favoring social cohesion in a society marked by religious diversity, and to the original model of interculturalism, or designate an ethical framework which translates into the paradigm of the recognition of the other linked to a requirement of reciprocity, or refer to a political project which unfolds at the same time in a quest for common values.

\section{Television Debates, a Specific Public Space and an Arena for Confronting Social Positions}

The State has for several years demonopolized the media field; a factor which explains the flowering of television channels and the competition observed between them and their programs. The demonopolisation of the media field by the State in Cameroon, we can say that this new era has had two consequences: the blossoming of television channels and the competition between them. In this regard, the country has gone from freedom of speech, which was first deployed during popular demands, to the manifestation of freedom of speech in the media, through debates. Nowadays, the organization of debates seems to be an increasingly popular formula in Cameroon, if we look at their multiplication in the audiovisual media. By definition, the televised debate refers to a discussion on a thematic around which individuals are called to express themselves. The televised debate can be based on dialogue (exchange between two or more individuals); its dis- 
course is often argumentative because each individual is driven by the will to impose his point of view, by resorting to discursive postures whose purpose can be linked to the fact of persuading or convincing his interlocutor or the public. Charaudeau and Ghiglione (op.cit.) explained that:

The televised debate is a form of exchange organized in such a way as to bring out the truth, whatever its configuration, about a problematized thematic, through the confrontation of different types of knowledge on the thematic, by means of a televisual device (organization, management, display) which allows the exposure of this knowledge and its confrontation to bring to light certain aspects of the problematization while being as intelligible as possible.

In Cameroon, debates broadcast by television channels deal with a variety of thematics and especially in relation to current affairs; the aim being to enlighten public opinion. It is important to note that the specificity of the televised debate is that it pits several guests against each other to express themselves on current affairs selected by a television channel. The debate is in essence contradictory. The debates last for a well-defined period of time and generally take an hour and a half and feature guests, presented as experts on specific issues. The actors on stage in televised debates, in their speeches, play games to seduce viewers whom they must convince. Television debates are therefore presented as structuring spaces where a moderator manages the interactions on a set, by sharing the stage with the speakers.

For the four programs studied, Scènes de presse; L'Arène; Club d'élite and Droit de réponse, the moderator, who is also a journalist, generally occupies the central position, controls the exchanges, and privileges his role of managing the exchanges. It should be mentioned, however, that these exchanges do not always take place in a harmonious environment. The televised debates that are the subject of this study are positioned much more as places of confrontation of symbolic powers and exposure of scientific knowledge or knowledge claimed by actors who are recruited from the academic, political, business, etc., sectors. As places where the positions of each of the actors are confronted, televised debates constitute a stake for those who participate in them but also for public opinion. Television debates have also become places for the promotion of actors, according to their status and their field of activity. In their speeches, the actors speak by addressing both the people in front of them and the viewers, present-absent at the blind spot targeted by the camera gaze. The televised debates combine a conversational device and a televisual device, both serving to problematize the reference theme. The four debates we study privileged the interview-debate. The framing of the televised debates studied favors the close-up, i.e. a way of showing affect in quality and power. The framing is carried out live, one of the distinctive features of television news. The actors on stage in televised debates thus construct a reality that is accentuated by the medium because it is the television channel that proposes the subjects for debate. The televised debates that concern us also have a structure that privileges some major ritual motifs, which the mode of enunciation specific to the television medium a fortiori contributes to develop and 
reinforce. Chabrol [29] further posits that if televised debates are governed by different types of contracts, they are also subject to various forms of ritualization. The staging of each program is based on a process of ritualization of verbal exchanges within a pre-constructed framework and on a process of dynamization of exchanges which depends on the initiatives taken by the guests present on the set. As far as the selection of participants is concerned, we noted that some actors make themselves available to the media and that others are rather solicited by the television channel.

\section{Anglophone Crisis as a Gateway to Debates on Social Cohesion.}

In general, we found that the crisis in the Anglophone regions is the starting point for debates on social cohesion. While the literature traces the origins of an "Anglophone problem" to the hegemonic agreements that led to the Reunification of Cameroon in 1961 (Dze Ngwa) [30], or presents identity-based mobilizations in the two Anglophone regions as attempts to take control of the state by returning to the question of locality since 1990 (Koum-Me-Tseny [31]; Abwa [32]), when it comes to giving their views on social cohesion, the speakers on the programs rely heavily on the crisis in the South-West and North-West regions, which they cite as a point of weakness in social cohesion, particularly on the programs Droit de réponse and L'Arène. In this vein, several speakers felt that the government (whose "harmful management and lack of openness" is totally to be denounced. Some believe that the construction of a way of living together can only be achieved through the return of peace in the two English-speaking regions. Most of the participants in the program Droit de réponse present themselves as influencers whose role is to draw the attention of viewers to the impossibility of building a way of living together with an Anglophone crisis and various problems in Cameroon. Living together is thus undermined through the discrediting of the government and its actions, which are described as ineffective. From a discursive point of view, most of the speakers developed the question of the management of the Anglophone crisis and the living together, through a sharp criticism of the actions of the State, in particular those related to the organization of the national dialogue. Some of the speakers, virulent in their language, also assert that the grand dialogue initiated by the head of state with the aim of managing the Anglophone crisis is a farce. The speakers generally constitute two camps that clashed: on tone hand, those who maintain that it is important to put pressure on a government that formulates pious wishes through the notion of living together, and on the other, speakers who oppose the ferocity of their opponents, the actions undertaken by the government to resolve the Anglophone crisis, in a spirit of social cohesion. On Club délites, it was noted that most of the speakers converged in the same direction, highlighting the efforts made by the government and insisting on the "living together", as it is built by the head of state. It was noted that on the set of Club $d$ Elites, an excessive discourse was developed that was in total contrast to the calmness that emerged from the program Scène de presse. Obama [33], presenter of Club d Elites and director of Vision4, openly attacked the Anglophone community, which he did not 
hesitate to describe on several occasions as the "enemies" of the nation: Some of the speakers, in the same vein, said that they were not aware of the existence of the "enemies" of the nation, people who were "manipulated by actors lurking in the shadows". Some speakers, in the same vein, did not hesitate to describe those who support the secession of Cameroon as unpatriotic, terrorists or enemies of Cameroon. On the set of the program Club d Elites, while they spoke of a "commendable decision" by the head of state, the speakers on the program Scène de Presse agreed with the presenter and spoke of a "helping hand from the Head of State" while several debaters on the program Droit de Réponse spoke of a new opportunity to consume taxpayers "money". As for the specific case of the Grand National Dialogue, the presenter of Droit de réponse even speaks of a festive meeting organized by the government, for members of the government and allied political parties. The Grand National Dialogue would therefore be, for those who intervene in the program Droit de réponse, a failure because the government in place does not really want to resolve the crisis in the Anglophone regions. It should also be noted that the "we" is used extensively by the speakers of the four programs, giving the impression that they speak on behalf of Cameroonians. Owona Nguini [34], an academician who is familiar with the programs, argues that the crisis in the Anglophone regions, at the political-symbolic level, represents an opportunity for the government to revive a certain nationalist orientation because the shock imposed by Boko Haram on Cameroon from its northern regions corresponded to a questioning of the capacity of the state of Cameroon to ensure its sovereignty over this part of the territory. Matomba [35] acknowledged that if it is true that the love we have for our country is enormous, then it is more important for us to know that our country is one and indivisible. He said he has travelled around Cameroon several times and today he can say that the problems faced by compatriots in the North West and South West are the same as those in the North, Far North, Adamaoua, East, South, Centre, Littoral, West, in short, all of Cameroon.

In summary, the discursive construction of the crisis in the four programs studied shows totally opposite points of view. While the will to resolve the crisis in the two Anglophone regions is clearly perceptible among the debaters of Scene de Presse, in the other three programs, there is talk of a conditioned reconciliation, or even a will to harm the nation. The discourse of distrust of the other, considered as an enemy, is also evident, and the idea of conspiracy is more prominent.

\section{"Living Together" in Televised Debates: a Mosaic of Meanings.}

Living together is a very recurrent topic in television debates. It is addressed in all the programs in our corpus and is the subject of discussions and even confrontations and is very often linked to subjects such as the crisis in the Anglophone regions. The actors generally involved in confrontations are recruited from several sectors of socio-economic life, notably the university sector, the clergy, civil society and politics.

The general observation that emerges is that several speakers approach living 
together as a constraint. In this context, it is noted that "When we start from the principle that living alone in a house has constraints, we must understand that as soon as there are two of us, the rules change according to certain people. We go out and arrive in another community; this community also organizes itself so that life is pleasant for everyone. This means that "we have to accept that there will be different opinions that we are diverse but we are together" (Tjomb) [36]. According to Momo [37], "hate speech and xenophobia undermine national unity, living together, social cohesion, national integration, sustainable peace and social stability. They structure the withdrawal of identity and contribute to the denigration and rejection of the other. Hate speech contributes to the exacerbation and instrumentalization of our differences. Everyday difficulties and claims, however relevant and legitimate they may be, should not authorize recourse to these practices, which negatively affect inter-community relations. This scourge is gaining ground. It is no longer cyclical, but is becoming systemic" (Club délites) [37].

One tendency brings the problem of living together back to a historical legacy and believes that the construction of the state in Cameroon ultimately proceeded from a colonial imagination, but very quickly reworked by the indigenous people who were to replace the colonial authority in the management of public services, not without echoing the colonial model of the manipulation of identities and tribes, that make up Cameroonian society as a whole. Others believe that the divide and rule theory, used by a certain elite through the subjugation of certain communities and community members, makes national unity in Cameroon utopian. The majority of the speakers believe, in spite of everything, that "the history of Cameroon is not that of brothers and sisters who fight each other, but that of a family that remains united in prosperity". So when we talk about Cameroon, our Cameroon, the cradle of our ancestors, the best choice will always be the choice of stability, and we note that the idea of acceptance is predominant: Living together means that each person in his culture and religion must be accepted by his Cameroonian brother and that "tribalism is not a negative phenomenon, but a form of social organization based on belonging to a tribe, which claims an ancestor, a language, a tradition, a tribe. It is a form of social organization based on belonging to a tribe, which claims an ancestor, a language, a tradition, a tribe, while admitting that it is the manipulation of ethnicity that is a problem" (Momo, op.cit.). For Djamen [38], "the tribe is a real brake on the development of Cameroon". Nguini Owona (op.cit.) on his part maintains that the complex and heterogeneous structure of Cameroon, linked to identities and cultures play an important role. The academician specifies that the difficulty that Cameroon's leaders have in unifying in an effective and consistent manner the different constituent segments of Cameroon is linked to the plurality of cultures and identities. Far from reducing the causes of this crisis to a failure of the government, Owona Nguini (ibid) noted that the solution lies in the mutual acceptance of the political unity of the Republic of Cameroon as a state and in a discussion on the institutional and constitutional compromise formula between federalism and 
advanced decentralization. An institutional form which would be a state of the regions based on the autonomous model (following the example of countries such as Italy and Spain) with a national consensus offering certain specific political and cultural competences to the English-speaking regions, taking into account their historical and cultural originality, without breaking the unity of the Republic of Cameroon, revealed the academician at Club d'élites. This multitude of opinions shows us that the positions are strongly influenced by the socioprofessional profiles of the various parties and that the speakers play on the audience of the television debates to convey their points of view. They are generally seen and presented as experts in specific fields. It should also be mentioned that the exchanges between speakers can be violent because very often one speaker supports the government's position and another refutes it. In his definition of the public space, Abolo Mbita [39] stresses that the latter, and precisely the modern public space, is the place where opinions cease to be expressed only in the street, where they are also expressed through institutions that can constitute representations of various actors in the sense that the media claim to speak on behalf of their audiences, by expressing their opinions in the public square, which ipso facto becomes public opinion. In this perspective, the positions taken by the speakers in televised debates could undoubtedly be considered as those of public opinion. Each speaker, in the speeches, tries to legitimize his or her point of view, based on his or her socio-political profile, even imposing these points of view on the other speakers. The particularity of the televised debate is that it constitutes a place for the construction of reality. The interlocutors of a televised debate thus appear as co-authors of a media narrative, in which they participate and into which they insert themselves to give it meaning. They thus participate in the co-construction of social cohesion through the interactions of those who intervene in the debates. Two major positions emerge: the first is that the idea of social cohesion is an utopia, given the inequalities in the distribution of wealth mentioned, and the second is that, it is possible to start from a multitude of identities and cultures to arrive at a common national consensus.

\section{Multiculturalism in Television Debates}

Multiculturalism is particularly discussed after the creation and establishment of the National Commission for the Promotion of Bilingualism and Multiculturalism. It evokes the problematic relationship between the political order, the social order and the cultural order, which raises the question of the expression of differences in the public space and also constitutes a political solution of the Cameroonian state in the face of the exacerbation of sub-national identities. Cameroon is in essence a multicultural country, with almost two hundred and fifty (250) national languages and cultures. If it is difficult to find a stabilized content of the notion of multiculturalism, it should be noted that the social perception of this notion is not easy. The televised debates that we have studied have enabled us to outline a definitional field of multiculturalism on the one hand, and to identify a Cameroonian specificity on the other. 


\section{Definitional Scope of Multiculturalism in Television Debates.}

Adopted in the context of the promotion of bilingualism, multiculturalism is perhaps not mentioned as much as living together in the television debates, but it must be noted that it is possible to highlight some content from the speeches of the speakers in the debates. Those who talk about multiculturalism agree on linking the issue to bilingualism. In this respect, it should be noted that the speakers do not agree on the concept of bilingualism: bilingualism can refer to the exclusive use of two languages or to the mastery of one language and the fact of understanding the other language, based on reality. Some even denounce the hegemony of French over English in Cameroon in general, based on bilingualism in the French-speaking area, while some speakers refer to the dominance or even exclusive use of English in the English-speaking areas. Other speakers maintain that bilingualism is a reality and at the same time a political will, due to the existence of private language centers which come to the rescue of those created by the state since 1989 and which welcome learners of all backgrounds and ages. In any case, there is a relationship of linguistic and cultural co-dominance in both the French and English speaking areas, an attitude that could be justified by an instinct for self-protection and identity withdrawal.

Thus, the speakers in the televised debates take bilingualism as a basis for giving content to multiculturalism. Some of them totally refute these two languages to advocate the enhancement of local languages, considered as true multicultural wealth, and arguing that colonization succeeded in teaching Cameroonians to despise their own cultural values and to aspire to Western values. In this context, languages, being part of cultural values, logically fall into this contempt to the benefit of languages that have become official. The state is also accused of being complicit in the neglect of not only mother tongues, but also ancestral cultures that are part of Cameroon's cultural heritage. For example, it is mentioned that holidays such as Christmas, Ramadan, Easter, Good Friday, etc. are institutionalized through days declared as non-working days, whereas this is not the case for commemorations such as the International Mother Language Day. Speakers who talk about multiculturalism almost put the State on trial, arguing that multiculturalism is a model of exclusion, because it prevents people from taking root. Thus, the State's choice of multiculturalism ultimately amounts to privileging the cultural referent to the detriment of a global civic vision of society, and thus threatens to fragment community identities, which are already numerous and active, a little more: "We have always been categorized, we talk about group, ethnicity[...]. We really need to make alliances with others. We have to see the individual, not the group. We have to stop thinking in terms of community", Matomba (op.cit.). However, some of the speakers evoked a completely different conception of multicultural policy. Some speakers would like the state to continue to recognize minority values and to allow the exercise of pluralist citizenship. On another level, some stakeholders see multiculturalism as an original policy where priority is given to a way of thinking, that is dominated by the principles of diversity, equality and tolerance of difference and, to a greater extent, translates into a set of notions 
and values that define a Cameroonian national identity.

In fact, the multicultural paradox ultimately illustrates the difficulty of harmonizing ethnic and national identity, or in other words, the complexity of the integrative process. Things are said about multiculturalism, but one emerges without a fixed definition. From the interventions, one could argue that multiculturalism raises the issue of dominance relations between majority and minorities and its impact on identity options. There is still a complete void in the definition of multiculturalism, associated with living together.

Cameroon's Approach to Multiculturalism: an Understanding through an Appreciation of the Commission set up.

The State, as the main guarantor of respect for the cultural orientations of individuals, seeks to promote a national identity to which all citizens can refer; this is the main reason for the creation of the National Commission for the Promotion of Bilingualism and Multiculturalism. In the aftermath of the establishment of this structure, voices were already being heard regarding doubts and apprehensions about the capacity of this new body to provide effective solutions. For many, this commission is in reality a consultative body, which appears to be an additional asset and a specific conceptual and practical framework to put more emphasis on Cameroonian cultures and traditions. Beyond the missions of studies, projects, promotion, sensitization and popularization relating to multiculturalism, it is responsible for receiving any request denouncing discrimination based on the disrespect of constitutional provisions relating to bilingualism and multiculturalism and reporting to the President of the Republic, says a speaker, while questioning the capacity of the body to carry out this mission. "It is difficult to expect anything from such an advisory body. The resolution of the sociopolitical crises undermining the country is a matter of governance, but this commission does not have the power to order reforms, its members took part in the Grand National Dialogue held at the beginning of October, but they had no decisive role in the organization and facilitation of exchanges. Nor does the commission have the means to track down and sanction the abuses that are observed in society". This is precisely the point of view of a speaker on the Club d Elites program [40]. Only a few weeks after the establishment of the body, a speaker said: "we do not feel the effects of this commission on the ground. Since its members were installed, hate speech between communities has increased. Even the Anglophone crisis, which was the reason for its creation, is still ongoing". Another concern expressed is that of opposing bilingualism and multiculturalism. For example, it was pointed out that if we stick to what has happened so far, the promotion of bilingualism, which is clearly marked in the Commission's terms of reference, risks swallowing up that of multiculturalism. Moreover, when comparing the terms bilingualism and multiculturalism, it is clear that the first, bilingualism, is precise and concise because it clearly refers to the official languages: French and English. Whereas the second, multiculturalism, is rather global and generic. Indeed, given the very kaleidoscopic definition of the term culture, one may wonder what the Commission's scope of action will be with respect to multicultural- 
ism.

Some speakers launch into a very sharp criticism of the Commission, pointing out that it was set up solely to squander financial resources. A regular on the Sunday news shows argues that since its creation, the Commission has been preoccupied with spending the 700 million budget released by the government and made available to it for the proper conduct of its activities on tourist parades. Otherwise, how can we interpret the silence of this Commission in the face of announcements of schism and appeals in the courts translating into hints of tribalism in mondo vision, that shake and divide some structures, like the Evangelical Church since the democratic election of a pastor from a different tribe from that of the outgoing pastor on April 22, 2017 at the synod of Ngaoundéré. Cases like these are very often cited on the televised debates, including the rise of tribalism on social networks. Alongside these opinions focused on the effectiveness of the commission, we note some interventions that go in another direction and which welcome this option of multiculturalism. Cases like these are often cited on the stage, including the rise of tribalism on social networks. Alongside these opinions focused on the effectiveness of the commission, there are a few interventions that go in another direction and welcome this option of multiculturalism. "We must learn to celebrate unity in our diversity by taking unity in diversity as an asset and not as a hindrance to our living together". The issue of identity withdrawal is very often raised when talking about multiculturalism. In fact, for most of the speakers, it is a notion that can only be understood in conjunction with tribality, tribalism and cultural diversity.

Abé [41], on the set of Club d Elites, underlines the interest and the opportunity to distinguish tribality from tribalism in order to understand identity-based withdrawal. This sociologist explained that: "Tribality is a link that individuals belonging to the same community or the same identity reference system maintain between them in order to articulate their cultural identity". However, it can happen that this identification with a communal referent slips into communalism. And one of the faces of communitarianism is tribalism. The latter is a form of exacerbation of tribality which takes the form of a withdrawal into identity. The withdrawal of identity here refers to an overvaluation of one's tribal belonging, with a rejection of otherness; of everything that is different from the in-group (between groups) to which one belongs. Invited on a set, a member of the Commission clarifies that Cameroonian multiculturalism and its daily praxis reveals the immanence of multicultural practice to the people of Cameroon. He reviewed both the conceptual and practical aspects of multiculturalism in the past and today, to confirm that the call of the President of the Republic to accept the other is a habit of the Cameroonian people. Respect for the law, the role of the elite, education and the establishment of a cultural watch guarantee, the survival of this system of values favorable to living together.

The concerns expressed by the speakers were more focused on the effectiveness of the commission set up for this purpose and the criticism of this government 
option.

\section{Conclusion}

At the beginning of this study, our general objective was to explore the possibilities of constructing a problematic in the public space, namely living together and social cohesion, by examining the way in which televised debates in Cameroon can contribute to the appearance of content in the public sphere on the subject of social cohesion and living together. We set out to show how living together is constructed on television with a selected panel of four programs: Scènes de presse, L'Arène, Club d' Élites and Droit de réponse during the period 2018-2019. If social cohesion is understood as the situation of a people living in perfect harmony with their socio-identitarian consciousness, it can also be perceived as the outcome of efforts at national pacification and reconciliation in a country plagued by social tensions and/or crises as is currently the case in Cameroon. It is this second bias that dominates the televised debates at the end of our analysis. Social cohesion is presented as the manifestation of "living together", in the sense that it implies an interweaving of identities between the different strata of the population with a view to their full participation in the construction of the whole society. Furthermore, "living together" is conditioned by the requirements of good governance, whereas at the level of public authorities, it is seen more as a political option. Living together and harmonious development are conditioned by the quality of governance, the deficit of which (re) introduces the desire to withdraw into one's identity. This is an obstacle to cultural diversity and development. On the whole, the arguments of the speakers in the debates studied identify the poor distribution of the country's socio-economic resources and the ineffectiveness of inclusive development. The study also led us to question multiculturalism, and it emerged that although the issue of cultural diversity in Cameroon was widely addressed in the debates, it was difficult to find a stable definition or content for this notion, as the exchanges were more focused on the effectiveness of the choices of the state. Multiculturalism is gradually becoming a reference point for the construction of public policies. Taking it into account allows the insertion of new institutional bodies, notably the national commission for the promotion of bilingualism and multiculturalism, by promoting new practices. Ultimately, the notion of multiculturalism reveals the complexity and the increasing complexity of allegiances to the state order.

\section{Conflicts of Interest}

The author declares no conflicts of interest regarding the publication of this paper.

\section{References}

[1] Nkoyok, J. (2019) Living Together and the Dynamics of the Social Link in Cameroon Which Cameroon Do We Want for Our Children? Edition Cheick AntaDiop, 
Collection Politique Africaine en Mutation, Douala, 524 p.

[2] Mbarga, D. (2020) Le challenge du vivre ensemble dans un contexte pluriethnique: le cas du Cameroun. Revue Française de Science Politique, Sciences Po University Press, Paris.

[3] Avodo, J. (2021) The Pre-Construct of Living Together in the Cameroonian Discursive Space. Jeynitaare: Pan-African Journal of Linguistics for Development, 1. https://doi.org/10.46711/jeynitaare.2021.1.1.1

[4] Kameni Wendeu, A.C. (2021) Media Discourse and Its Impact on the Construction of the Living Together in Cameroon. A Panoramic Look at Two Daily Newspapers: "Cameroon Tribune" and "Le Messager". Jeynitaare: Revue Panafricaine de Linguistique pour le Développement, 1.

https://doi.org/10.46711/jeynitaare.2021.1.1.3

[5] Balandier, G. (1989) Le Lien Social en Question. Cahiers internationaux de Sociologie, LXXXVI, 5-13.

[6] Burger, M. (1994) Identity Construction in Verbal Interaction: Aspects of Enunciative Identity Success. Cahiers de Linguistique Française, Words and Discourses. Contrastive Studies and Perspectives, No. 34, 101-122.

[7] Amossy, R. (2014) Apologie de la polémique. PUF, Coll. L'interrogation Philosophique, Argumentation et Analyse du Discours, Paris, 240.

https://doi.org/10.3917/puf.amos.2014.01

[8] Doury, M. and Moirand, S. (2005) Argumentation Today. Theoretical Positions in Confrontation, Presses de la Sorbonne Nouvelle, Paris, 200 p.

[9] Plantin, C. (1996) Le trilogue argumentatif. Présentation de modèle, analyse de cas. Langue Française, 9-30. https://doi.org/10.3406/lfr.1996.5358

[10] Fortin, G. (2006) Une dérive néo-sophistique? Les pratiques argumentatives dans les débats politiques télévisés. Communication et Langages, 148, 53-67. https://doi.org/10.3406/colan.2006.4596

[11] Adam, J.-M. (1992) Les Textes Types et Prototypes. Récit, Description, Argumentation, Explication et Dialogue. Université/Seuil, Paris, 240.

[12] Bourdieu, P. (1996) Sur la télévision. Suivi de l'emprise du journalism. Raisons d'agir, Paris, 96.

[13] Ducrot, O. (1991) Dire et ne pas dire, Paris, Hermann. $3^{3 e ̀ m e}$ Édition, Corrigée et Augmentée, 210.

[14] Ghiglione, R. and Matalon, B. (1988) Sociological Surveys: Theory and Practice. Armand Colin, Paris, 288.

[15] Kerbrat-Orecchioni, C. (1986) L'implicite. A. Colin, Paris, 404 p.

[16] Maingueneau, D. (1998) Analysing of Communication Texts. Dunod, Paris, 280 p.

[17] Véron, E. (1983) Il est là, je le vois, il me parle. Communications, 38, 98-120. https://doi.org/10.3406/comm.1983.1570

[18] Matsanga Nziengui, M. (2018) The Production and Dissemination of Culture in African Public Television Channels. The Gabonese Experience, Université Grenoble Alpes, Saint Martin d'Hères, 486 p.

[19] Nel, N. (1990) Le débat televise. Armand Colin, Paris 271 p.

[20] Rouquette, S. (2003) Vie et mort des débats télévisés 1958 2000. Communication, 22, 250-252. http://journals.openedition.org/communication/4573

[21] Nga Ndongo, V. (2020) Débats ou combats télévisés? Esquisse de socioanalyse du jeu médiatico-politique au Cameroun. L'Harmattan, Yaoundé, 92 p. 
[22] Charaudeau, P. and Ghiglione, R. (1997) La parole confisquée. Un Genre Télévisuel: Le Talkshow, Dunod, Paris, 296 p.

[23] United Nations Educational, Scientific and Cultural Organization (2003) Learning to Live Together: Have We Failed? UNESCO International Bureau of Education, 168 p.

[24] Fall, K. (2015) De quoi l'expression "le vivre-ensemble" est-il le nom? Cartographie d'une notion'. In: Saillant F., Ed., Pluralité et Vivre Ensemble, Presses de l'Université Laval, Québec, 21-36.

[25] Broquet, H. (2007) Les nouveaux défis du "vivre ensemble": Citoyennetés, cultures et démocratie. Charles Roi, Bruxelles, 126 p.

[26] Touraine, A. (2020) Pourrons-nous vivre ensemble? Fayard, Paris, p. 396.

[27] Larousse (2018) Dictionnaire Larousse poche. Anniversaire Bicentenaire Pierre Larousse, Paris, $1067 \mathrm{p}$.

[28] Constitution du Cameroun (1996) Loi $\mathrm{n}^{\circ} 96 / 06$ du 18 janvier 1996 portant révision de la Constitution du 02 juin 1972, modifiée et complétée par la loi $n^{\circ} 2008 / 001 \mathrm{du}$ 14 avril 2008, Yaoundé.

[29] Chabrol, C. and Guérif, F. (2004) Comment Faire un Film? Payot et Rivages, Paris, $98 \mathrm{p}$.

[30] Dze Ngwa, W. (1998) The Anglophone Problem in Cameroon: A Historical Perspective, 1916-1995. Maîtrise en Histoire thesis, University of Yaoundé I, Yaoundé, 520 p.

[31] Nkoum-Me-Ntseny, L.-M. (1996) Dynamique de positionnement anglophone et libéralisation politique au Cameroun: de l'identité à l'identification. Polis/ Revue camerounaise de science politique, 1, 68-100.

[32] Abwa, D. (2000) Le problème anglophone au Cameroun: Facteur d'intégration ou de désintégration nationale? In: Dubois, C., Ed., Frontières plurielles, frontières conflictuelles en Afrique subsaharienne, L'Harmattan, Paris, 115-141.

[33] Obama, E. (2018) Club d'élites du 03 Juin 2018.

[34] Owona Nguini, M. (2018) Club d'élites du 10 Juin 2018.

[35] Matomba, S.-E. (2018) Scène de Presse du 17 Juin 2018.

[36] Tjomb Yamb, T.C. (2019) Cameroon, Tribalism in Religion Is a Reproduction of the Political Field. Interview with Claude Abé. Yaoundé, Cameroon Tribune.

[37] Momo, J.-De-D. (2018) Club d'élites du 4 Février 2018.

[38] Djamen, C. (2019) Droit de Réponse, mars 2019.

[39] Abolo Mbita, C. (2020) Médias, politique et opinion publique: Les logiques d'influence. Afrédit, Yaoundé, 170p.

[40] Essomba, E. (2018) Club d'Elites Program, Émission du 4 Février 2018.

[41] Abé, C. (2019) Club d'élites, Mai 2018. 